\title{
Combined Suppression of the Intrarenal and Circulating Vasoconstrictor Renin-ACE-ANG II Axis and Augmentation of the Vasodilator ACE2-ANG 1-7-Mas Axis Attenuates the Systemic Hypertension in Ren-2 Transgenic Rats Exposed to Chronic Hypoxia
}

\author{
L. ČERVENKA ${ }^{1,2}$, J. BÍBOVÁ ${ }^{3}$, Z. HUSKOVÁ ${ }^{2}$, Z. VAŇOURKOVÁ ${ }^{2}$, H. J. KRAMER ${ }^{4}$, \\ J. HERGET ${ }^{3}, \check{S}^{\text {. JÍCHOVÁ }}{ }^{2,3}$, J. SADOWSKI ${ }^{5}$, V. HAMPL $^{3}$ \\ ${ }^{1}$ Department of Pathophysiology, Second Faculty of Medicine, Charles University, Prague, Czech \\ Republic, ${ }^{2}$ Center for Experimental Medicine, Institute for Clinical and Experimental Medicine, \\ Prague, Czech Republic, ${ }^{3}$ Department of Physiology, Second Faculty of Medicine, Charles \\ University, Prague, Czech Republic, ${ }^{4}$ Section of Nephrology, Medical Policlinic, Department of \\ Medicine, University of Bonn, Bonn, Germany, ${ }^{5}$ Department of Renal and Body Fluid Physiology, \\ M. Mossakowski Medical Research Centre, Polish Academy of Science, Warsaw, Poland
}

Received June 5, 2014

Accepted June 11, 2014

On-line September 5, 2014

\section{Summary}

The aim of the present study was to test the hypothesis that chronic hypoxia would aggravate hypertension in Ren-2 transgenic rats (TGR), a well-defined monogenetic model of hypertension with increased activity of endogenous reninangiotensin system (RAS). Systolic blood pressure (SBP) in conscious rats and mean arterial pressure (MAP) in anesthetized TGR and normotensive Hannover Sprague-Dawley (HanSD) rats were determined under normoxia that was either continuous or interrupted by two weeks' hypoxia. Expression, activities and concentrations of individual components of RAS were studied in plasma and kidney of TGR and HanSD rats under normoxic conditions and after exposure to chronic hypoxia. In HanSD rats two weeks' exposure to chronic hypoxia did not alter SBP and MAP. Surprisingly, in TGR it decreased markedly SBP and MAP; this was associated with substantial reduction in plasma and kidney renin activities and also of angiotensin II (ANG II) levels, without altering angiotensin-converting enzyme (ACE) activities. Simultaneously, in TGR the exposure to hypoxia increased kidney ACE type 2 (ACE2) activity and angiotensin 1-7 (ANG 1-7) concentrations as compared with TGR under continuous normoxia. Based on these results, we propose that suppression of the hypertensiogenic ACE-ANG II axis in the circulation and kidney tissue, combined with augmentation of the intrarenal vasodilator ACE2-ANG 1-7 axis, is the main mechanism responsible for the blood pressure-lowering effects of chronic hypoxia in TGR.

\section{Key words}

Hypertension • Chronic hypoxia • Renin-angiotensin system

\section{Corresponding author}

L. Červenka, Department of Pathophysiology, Second Faculty of Medicine, Charles University, Prague, Czech Republic. E-mail: luce@medicon.cz

\section{Introduction}

It is now generally accepted that abnormal activation of the systemic and intrarenal reninangiotensin system (RAS) is a crucial factor in pathophysiology of hypertension (Kobori et al. 2007, Gonzalez-Vilalobos et al. 2013). Nevertheless, effects of hypoxia on the activity of the RAS and on blood pressure (BP) regulation in normotensive and especially in hypertensive subjects have not been clearly established. Some studies showed that hypoxia increased the activity of the RAS (Frayser et al. 1975, Zakheim et al. 1976, 
Rose et al. 1983, Morrell et al. 1995, Hubloue et al. 2004) while others demonstrated a decrease in BP and RAS activity (Antezana et al. 1995, Krebs et al. 1999, Hoehne et al. 2001, Vilar et al. 2008). Therefore, the role of RAS in the pathophysiology of arterial hypertension and especially the BP response to chronic hypoxia remains the subject of further research.

We reasoned that the discrepancies in the findings concerning the effects of chronic hypoxia on the activity of the RAS and systemic arterial BP are related to the experimental model that was used in most studies. In ANG II-infused rats, a most common model of RASdependent hypertension, high BP results from chronic infusion of originally subpressor doses of ANG II, which leads to a marked suppression of plasma renin activity and renal renin content (Zou et al. 1998, Kobori et al. 2007) indicating that the activity of the endogenous RAS is suppressed. Therefore, it is logical to assume that the effects of chronic hypoxia observed under RAS suppression would differ from those seen in normotensive rats with normal endogenous RAS activity or, even more so, from the effects observed in hypertensive rats with hypertension dependent on increased endogenous RAS activity (ANG II-dependent, as opposed to ANG II-induced hypertension). Therefore, for evaluation of the role of the RAS in the arterial BP responses to chronic hypoxia, we decided to use in this study a Ren-2 renin transgenic rat strain (TGR). TGR represent a unique well-defined monogenetic model of hypertension, in which hypertension is clearly related to the insertion of a mouse Ren- 2 renin gene into the genome of normotensive Hannover Sprague-Dawley (HanSD) rats (Mullins et al. 1990). TGR exhibit increased circulating and tissue concentrations of ANG II as compared with age-matched HanSD rats (Husková et al. 2006a, Neckáŕ et al. 2012). In our opinion, studies using this model should help evaluate the precise nature of the relationship between the enhanced activity of the endogenous RAS and the effects of exposure to chronic hypoxia in the regulation of systemic BP.

Based on the above considerations, we hypothesized that chronic hypoxia would aggravate hypertension in TGR. To further elucidate the mechanism(s) underlying alterations of the RAS in response to chronic hypoxia, expressions of individual components of the RAS and their activities/ concentrations were determined in plasma and tissues of TGR and HanSD rats, both under normoxic conditions and after exposure to chronic hypoxia. Given the importance of the interaction of RAS with other vasoactive systems, such as sympathetic nervous systems, in the pathophysiology of ANG II-dependent hypertension and in the mediation of cardiovascular responses to chronic hypoxia (Kobori et al. 2007, Guild et al. 2012, Jankovski et al. 2013), we also determined plasma and tissue catecholamine levels in TGR and HanSD rats, both under normoxic conditions and after exposure to chronic hypoxia.

\section{Materials and Methods}

The studies were performed in accordance with guidelines and practices established by the Animal Care and Use Committees of the Institute for Clinical and Experimental Medicine and of the $2^{\text {nd }}$ Faculty of Medicine.

\section{Animals}

All animals used in the present study were bred at the Center for Experimental Medicine from stock animals supplied from Max Delbrück Center for Molecular Medicine, Berlin (we acknowledge the generous gift of Drs. Bader and Ganten). The TGR rat strain was constructed by inserting the mouse Ren-2 renin gene, including $5 \mathrm{~kb}$ of 5 '-flanking sequences and $9 \mathrm{~kb}$ 3 '-flanking sequences into the rat genome of HanSD rats. Heterozygous TGR were generated by breeding male homozygous TGR with female homozygous HanSD rats as described and verified in the original study (Mullins et al. 1990). Animals were fed a standard rat chow containing $0.4 \%$ sodium chloride (SEMED, Prague, Czech Republic), with free access to tap water.

\section{Experimental design}

Series 1: Effects of chronic hypoxia on systolic BP (SBP) in TGR and HanSD rats

Beginning from 55 days of age, in appropriately trained conscious animals SBP was measured every second day by tail-pletysmography, using a tail-cuff apparatus (MC 4000; Hatteras Instruments Co., Cary, NC, USA); in all cases a mean systolic BP (SBP) of 4 measurements was taken. In accordance with recommendation for $\mathrm{BP}$ measurements in experimental animals (Kurtz et al. 2005), this method is adequate for detecting intergroup differences in SBP over time and therefore is optimal for long-term studies. This method is regularly used in our laboratory (Cervenka and Heller 1996, Kujal et al. 2010, 2014) and was previously 
validated: a close correlation was found between SBP measurements by tail-pletysmography and direct BP measurements using an indwelling catheter in conscious rats. Between the days of age 66 and 80 (for 14 days) the animals were exposed to chronic normobaric hypoxia $\left(10 \% \mathrm{O}_{2}\right)$ using isobaric hypoxic chamber as described in detail in our previous studies (Herget et al. 1996, Hampl et al. 2003). For the procedure of measurements of SBP, rats were removed from the hypoxic chamber for not more than $2 \mathrm{~h}$. During SBP measurements body weight (BW) was also monitored. Beginning from the day of age 81 the exposure to hypoxia was ceased and until the day 125 all rats were maintained in normoxia. The following experimental groups were examined:

1. TGR + hypoxia (between days of age 66 and 80) $(\mathrm{n}=10)$

2. TGR + continuous normoxia $(n=9)$

3. HanSD + hypoxia $(n=8)$

4. HanSD + continuous normoxia $(n=8)$

At the end of experiments, animals were anesthetized with sodium thiopental (40 mg/kg, i.p.) and left carotid artery was catheterized for measurement of mean arterial pressure (MAP). For assessment of cardiac hypertrophy, the ratio of left ventricle weight (LVW) to tibia length (TL) was employed. It has been shown that tibia length is independent of changes in BW, and the above ratio is the most suitable index for assessment of cardiac hypertrophy (Husková et al. 2010, Kujal et al. 2010, 2014, Vaňourková et al. 2006).

Series 2: Effects of chronic hypoxia on MAP in TGR and HanSD rats

In this series TGR and HanSD rats were subjected to the same protocol as described in series 1 , up to the 80 th day of age. On day 80 of age (i.e. on day 14 of exposure to hypoxia) MAP was directly measured and the degree of cardiac hypertrophy was determined as described for series 1 . The following experimental groups were examined:
1. TGR + hypoxia $(n=7)$
2. TGR + continuous normoxia $(n=7)$
3. HanSD + hypoxia $(n=6)$
4. HanSD + continuous normoxia $(n=7)$

Series 3: Effects of chronic hypoxia on expression and activities of individual components of the RAS, and on epinephrine, norepinephrine and dopamine levels

In this series TGR and HanSD rats were subjected to the same protocol as animals in series 2 . The following experimental groups were examined:

1. $\mathrm{TGR}+$ hypoxia $(\mathrm{n}=9)$

2. $\mathrm{TGR}+$ continuous normoxia $(\mathrm{n}=10)$

3. HanSD + hypoxia $(n=9)$

4. HanSD + continuous normoxia $(n=10)$

Since it is now well recognized that plasma and tissue ANG II concentrations in anesthetized animals are higher than those obtained from decapitated conscious rats, and that normotensive animals exhibit greater increases in renin secretion in response to anesthesia and surgery than do ANG II-dependent hypertensive animals (Husková et al. 2006a,b), in the present study rats from each experimental group were decapitated at the age of 80 days (i.e. on day 14 of exposure to hypoxia) and plasma and tissue samples were collected. This approach which is routinely used in our laboratory, allows comparison of the present results with those of our previous studies performed to evaluate the role of the RAS in the pathophysiology of hypertension and end-organ damage (Husková et al. 2006a,b, 2010, Vaňourková et al. 2006, Červenka et al. 2008, Bürgelová et al. 2009, Kujal et al. 2010, 2014, Neckář et al. 2012, Varcabová et al. 2013). Plasma and kidney tissue renin, angiotensin-converting enzyme (ACE) and angiotensinconverting enzyme type 2 (ACE2) activities and angiotensin I (ANG I), ANG II and angiotensin-(1-7) (ANG 1-7) levels and tissue concentrations of catecholamines were measured as described previously (Červenka et al. 2008, Bürgelová et al. 2009, Husková et al. 2010). In addition, rat and mouse renin gene, the expression of ANG II type $1\left(\mathrm{AT}_{1}\right)$ receptor and G-protein-coupled receptor Mas gene (as a functional receptor for ANG 1-7) in the kidney, and ACE and ACE2 gene expression in the kidney were determined as described previously (Nogueira et al. 2007, Bürgelová et al. 2009, Wong et al. 2012). Briefly, total RNA was extracted from liver, kidney and lung tissue using TRIzol ${ }^{\circledR}$ Reagent (Life Technologies, Prague, Czech Republic) according to the manufacturer's directions. DNase I (Fermentas, Thermoscientific, Waltham, MA, USA)-treated total RNA was reverse transcribed and amplified using One Step SYBR $^{\circledR} \quad$ PrimeScript $^{\mathrm{TM}}$ RT-PCR Kit II (TAKARA BIO INC, Shiga, Japan) in the total volume of $20 \mu \mathrm{l}$. All samples were analyzed in triplicates.

The primers were designed by Primer3 software. Primer sequences were: 
rRen1 (rat renin):

forward 5'-GGCTGTTGATGGAGTCATCC-3'

reverse 5'-AGCCGGCCTTGCTGAT-3'

mRen2 (mouse renin):

forward: 5'-GCCTCAGCAAGACTGATTCC-3'

reverse: 5'-ATATTCATGTAGTCTCTTCTCC-3'

$\mathrm{AT}_{1}$ receptor:

forward: 5'-CCAAGATGACTGCCCCAAG-3'

reverse: 5'-ATCACCACCAAGCTGTTTCC-3'

$\beta$-actin:

forward: 5'-TGACTGACTACCTCATGAAGA-3'

reverse: 5'-CACGTCACACTTCATGATG-3'

ACE:

forward: 5'-TCCTATTCCCGCTCATCTGC-3'

reverse: 5'-CCAGCCCTTCTGTACCATT-3'

ACE2:

forward: 5'-GAATGCGACCATCAAGCGTC-3' reverse: 5'-CAAGCCCAGAGCCTACGAT-3'

Mas receptor:

forward: 5'-CCTGCATACTGGGAAGACCA-3'

reverse: 5'-TCCCTTCCTGTTTCTCATGG-3'

PCR amplifications were performed using the Light Cycler® 96 Real-Time PCR System (Roche, Prague, Czech Republic) following the reaction parameters recommended by the manufacturer, using $2 \mathrm{mg}$ RNA per sample. $\beta$-actin was used as an endogenous control gene and negative controls contained water instead of cDNA. In all experiments, relative gene expression was calculated by the $\Delta$ cycle threshold $(\mathrm{Ct})$ method. Briefly, the resultant mRNA was normalized to a calibrator; in each case, the calibrator chosen was a group of HanSD rats on continuous normoxia. Final results were expressed as the n-fold difference in gene expression relative to $\beta$-actin mRNA and calibrator as follows: $n$-fold $=2^{-(\Delta \mathrm{Ct} \text { sample/ } \Delta \mathrm{Ct} \text { basal })}$, where $\Delta \mathrm{Ct}$ values of the sample and calibrator were determined by subtracting the average $\mathrm{Ct}$ value of the transcript under investigation from the average $\mathrm{Ct}$ value of the $\beta$-actin mRNA gene for each sample. Plasma and tissue concentrations of epinephrine, norepinephrine and dopamine were analyzed by ELISA employing commercially available kits (Tricat ELISA, IBL International, and GmbH, Germany), in accordance with the manufacturer's instructions.

Western blot analyses of kidney cortex $\mathrm{AT}_{1}$ receptor protein expression was performed as described recently (Harrison-Bernard et al. 1999, 2002, Husková et al. 2006a, Herrera et al. 2013) and we viewed with caution the notion about potential problems with nonspecific binding in kidney tissues of commercially available anti- $\mathrm{AT}_{1}$ receptor antibodies and therefore, as suggested (Herrera et al. 2013), we employed two different antibodies (Alomone Labs, Israel, and Santa Cruz, USA), and the data were analyzed only if the results obtained were identical.

Western blot analyses of kidney cortex Mas receptor protein expression and ACE2 were performed as described recently (Bürgelová et al. 2009, Giani et al. 2012, Wong et al. 2012) by employing commercially available antibodies (Alomone Labs, Israel and Gene Tex, USA). Again, the ratio LVW/TL was assessed.

\section{Statistical analysis}

All values are expressed as means \pm SEM. Using Graph-Pad Prism software (Graph Pad Software, San Diego, CA, USA), statistical analysis was performed by Student's $t$-test, Wilcoxon's signed-rank test for unpaired data, or one-way analysis of variance (ANOVA) as appropriate. ANOVA for repeated measurements, followed by Student-Newman-Keuls test was performed for the analysis within groups (e.g. for analysis of effects of 14 days' hypoxia on SBP). Values exceeding the $95 \%$ probability limits $(\mathrm{P}<0.05)$ were considered statistically significant.

\section{Results}

Series 1: Effects of chronic hypoxia on SBP in TGR and HanSD rats

As shown in Figure 1A, before exposure to hypoxia TGR were markedly hypertensive $(207 \pm 5 \mathrm{~mm} \mathrm{Hg})$ and 14 days' exposure to hypoxia resulted in a significant decrease in SBP (to $148 \pm 4 \mathrm{~mm} \mathrm{Hg} ; \mathrm{P}<0.05$ compared with initial values). After cessation of hypoxia, SBP gradually returned to levels observed in TGR maintained on continuous normoxia, and between day 105 of age and the end of the study no significant differences between these two groups were seen $(201 \pm 7$ vs. $206 \pm 4 \mathrm{~mm} \mathrm{Hg})$. Exposure to hypoxia had no effect on SBP in HanSD rats and there were no significant differences in SBP between the two groups of HanSD rats. Direct measurements of MAP at the end of experiment (on day 125 of age) confirmed that there were no significant differences between TGR maintained on continuous normoxia and TGR exposed to 14 days of hypoxia (162 \pm 5 vs. $159 \pm 4 \mathrm{~mm} \mathrm{Hg})$. In addition, at the end of experiment there were no significant differences between these two groups of TGR in the degree of cardiac hypertrophy (expressed as 
LVW/TL) and these ratios were markedly higher compared with HanSD rats exposed to continuous normoxia (30.6 \pm 1.1 and $30.2 \pm 0.9$ vs. $23.1 \pm 0.4, \mathrm{P}<0.05$ in both cases). At the end of experiment, there were no significant differences in MAP and LVW/TL between HanSD rats maintained on continuous normoxia and HanSD rats exposed to 14 days of hypoxia.

\section{Series 2: Effects of chronic hypoxia on MAP in TGR and HanSD rats}

As shown in Figure 1B, the 14 days' exposure to hypoxia reduced MAP in TGR as compared with TGR exposed to continuous normoxia (105 \pm 4 vs. $157 \pm 3 \mathrm{~mm} \mathrm{Hg}, \mathrm{P}<0.05$ ), but did not alter it in HanSD rats. There were no significant differences in $\mathrm{BW}$ between TGR and HanSD rats maintained on continuous normoxia ( $329 \pm 12$ vs. $341 \pm 9 \mathrm{~g})$ and the two weeks' exposure to hypoxia elicited similar decreases in BW in TGR and in HanSD rats (to $240 \pm 8$ and to $238 \pm 4 \mathrm{~g}$, in both cases different from normoxia at $\mathrm{P}<0.05$ ). As shown in Figure 1C, TGR on continuous normoxia exhibited severe left ventricle hypertrophy (expressed as LVW/TL) as compared to HanSD rats, and 14 days' exposure to chronic hypoxia elicited a significant decrease in this ratio in TGR $(\mathrm{P}<0.05$ when compared with $\mathrm{TGR}$ in continuous hypoxia).

Series 3: Effects of chronic hypoxia on expression and activities of individual components of the RAS, and on epinephrine, norepinephrine and dopamine levels

Figures $2 \mathrm{~A}$ and $2 \mathrm{~B}$ show that under continuous normoxia plasma ANG II levels and plasma renin activity were markedly higher in TGR than in HanSD rats $(62 \pm 9$ vs. $34 \pm 7 \mathrm{fmol} / \mathrm{ml}$ and $7.12 \pm 0.81$ vs. $5.27 \pm 0.63 \mathrm{ng}$ ANG I.ml ${ }^{-1} \cdot \mathrm{h}^{-1}, \mathrm{P}<0.05$ in both cases). The exposure to hypoxia resulted in significant decreases in plasma ANG II levels and in plasma renin activity to values similar in TGR and HanSD rats. As shown in Figures 2C and 2D, plasma ACE activity measured either directly or estimated as the ratio of ANG II to ANG I did not significantly differ between TGR and HanSD rats maintained in continuous normoxia, and were not altered by exposure to hypoxia. Likewise, plasma ANG 1-7 and plasma ACE2 activity did not significantly differ between TGR and HanSD rats in continuous normoxia, and exposure to hypoxia did not change them significantly (Figs 2E and 2F).

There were no significant differences in plasma epinephrine, norepinephrine and dopamine levels between TGR and HanSD rats in continuous normoxia ( $2.86 \pm 0.29$ vs. $3.34 \pm 0.33,1.71 \pm 0.14$ vs. $1.72 \pm 0.26 \mathrm{ng} / \mathrm{ml}$ and $70.4 \pm 4.1$ vs. $75.2 \pm 3.9 \mathrm{pg} / \mathrm{ml}$ ) and the exposure to hypoxia did not alter them in TGR or HanSD rats.

A

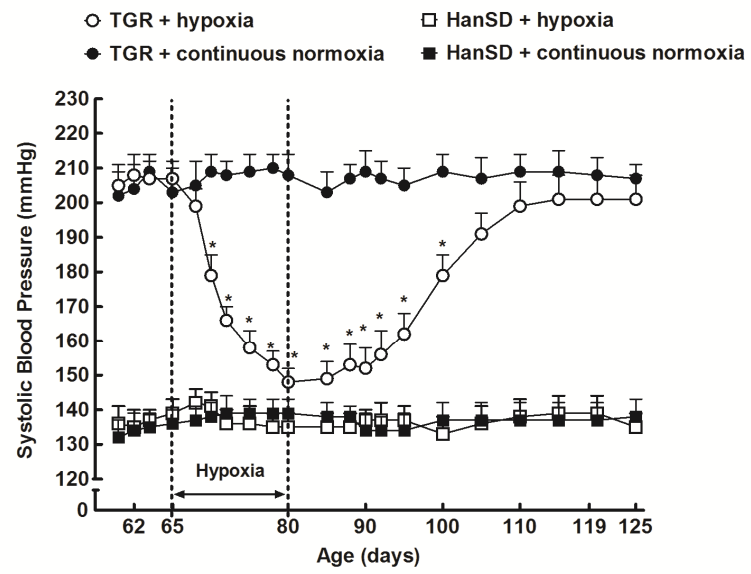

B

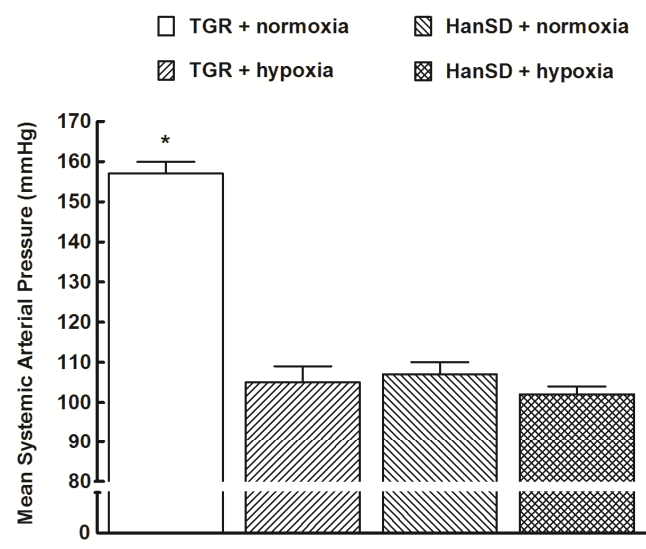

C

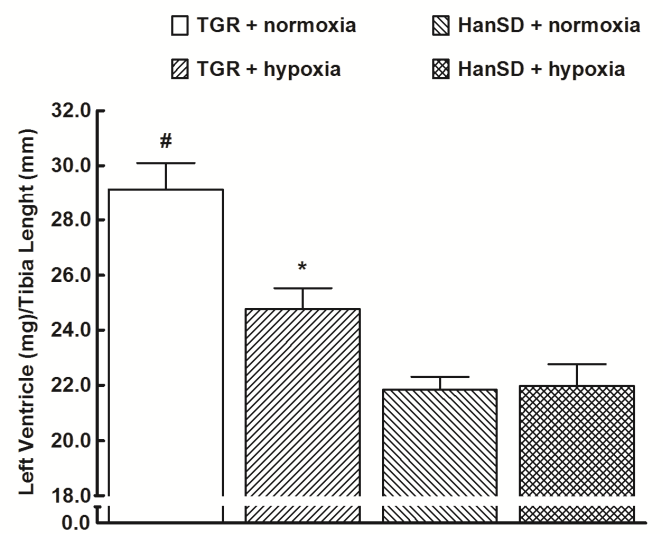

Fig. 1. Changes in systolic blood pressure (A), mean arterial pressure (B) and the ratio of left ventricle weight to tibia length (C) after 14 days' exposure to chronic hypoxia (on day 80 of age) in TGR (heterozygous Ren-2 renin transgenic rats) or HanSD (transgene-negative) rats. Values are means \pm SEM. $* \mathrm{P}<0.05$ vs. corresponding basal values (i.e. before exposure to chronic hypoxia) or vs. unmarked values on the same day. 
A

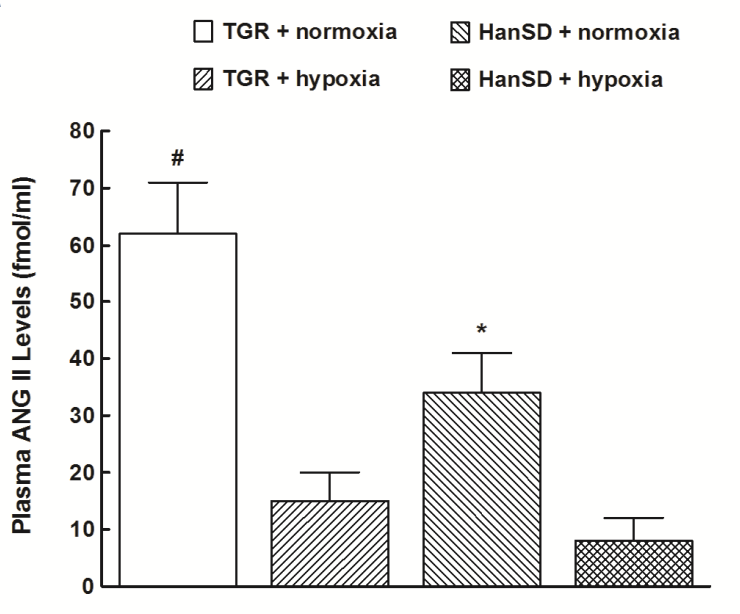

B

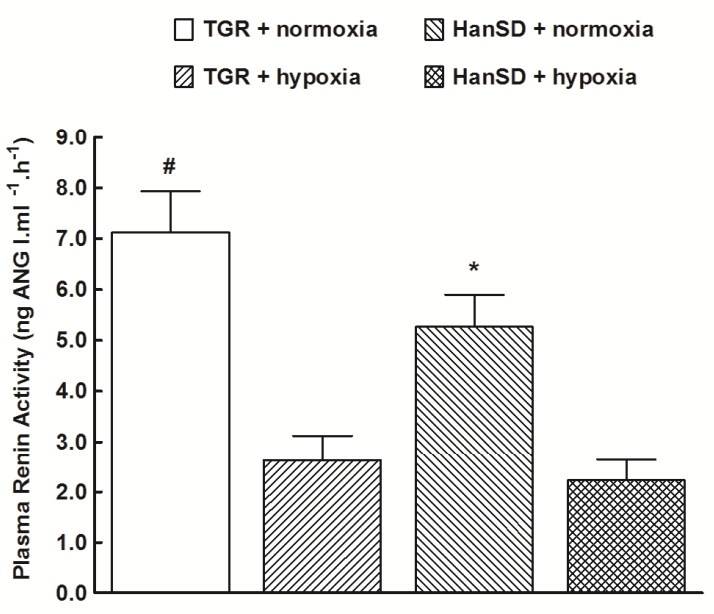

C

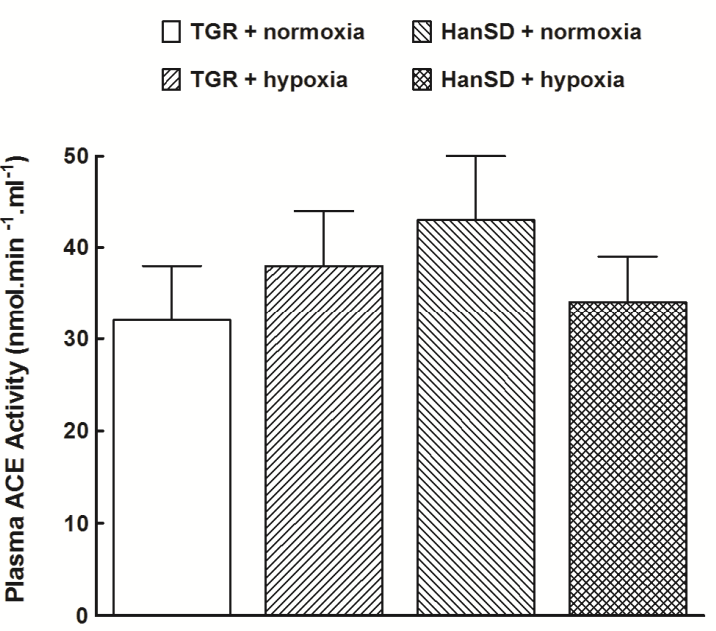

D
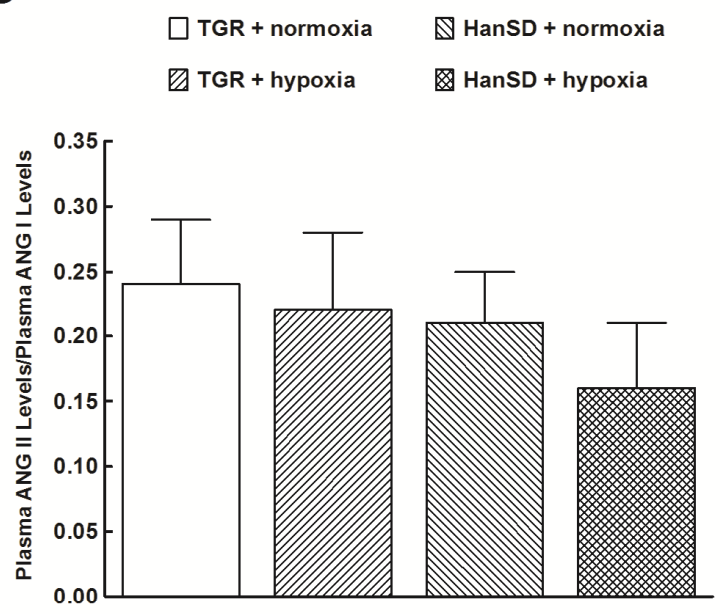

E

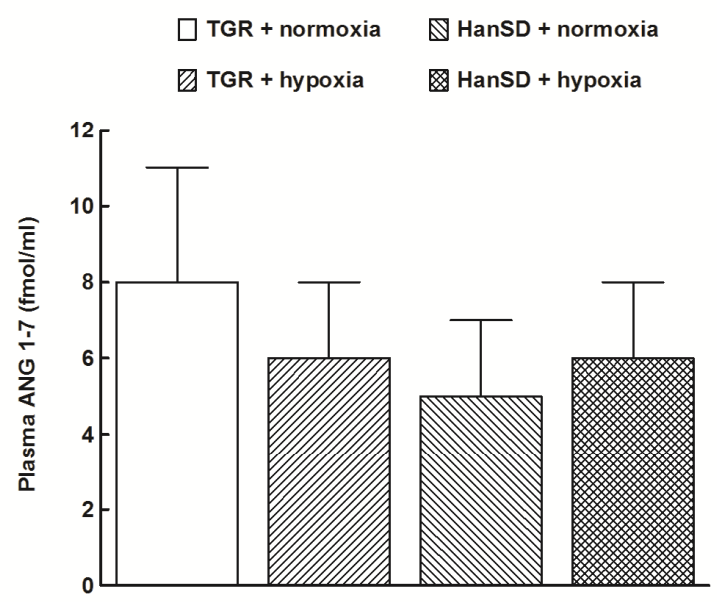

$\mathbf{F}$

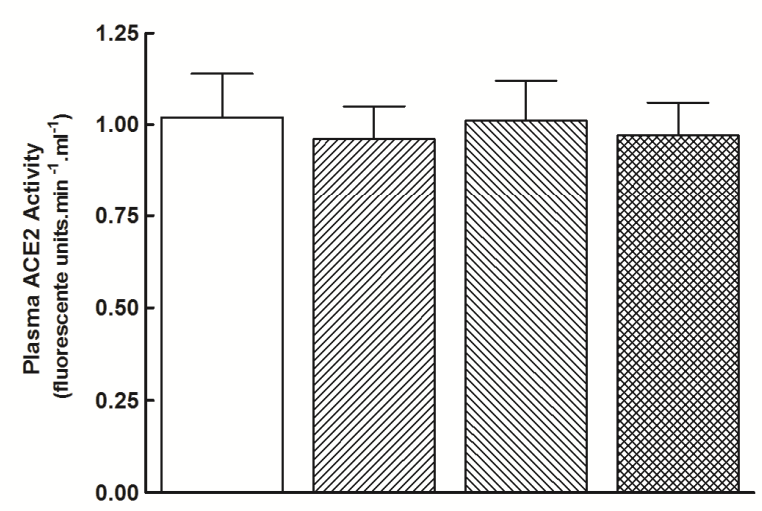

Fig. 2. Plasma angiotensin II (ANG II) levels (A), plasma renin activity (B), plasma angiotensin-converting enzyme (ACE) activity (C), the ratio of plasma ANG II to angiotensin I (ANG I) levels (D), plasma angiotensin 1-7 (ANG 1-7) levels (E) and plasma angiotensinconverting enzyme type 2 (ACE2) activity (F) in TGR (heterozygous Ren-2 renin transgenic rats) and HanSD (transgene-negative) rats. Values are means \pm SEM. $* P<0.05$ vs. unmarked values; ${ }^{*} \mathrm{P}<0.05$ vs. all the other values. 
A
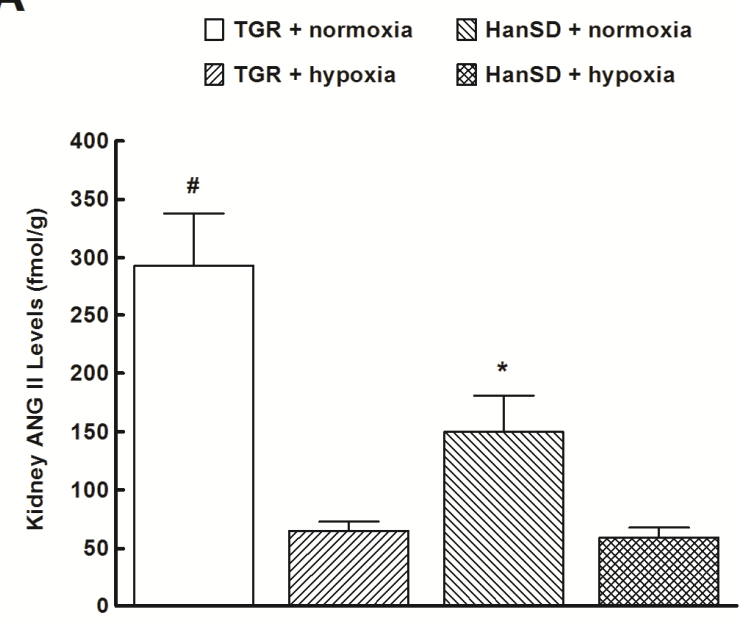

B

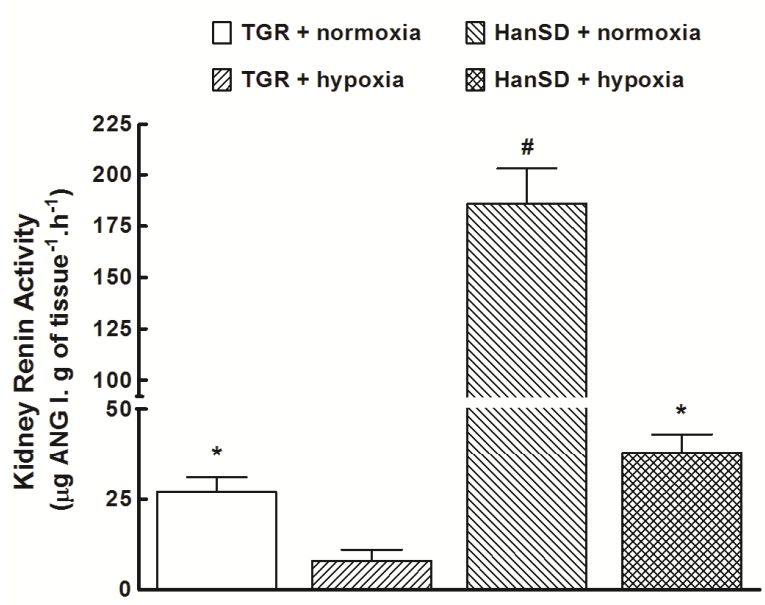

C

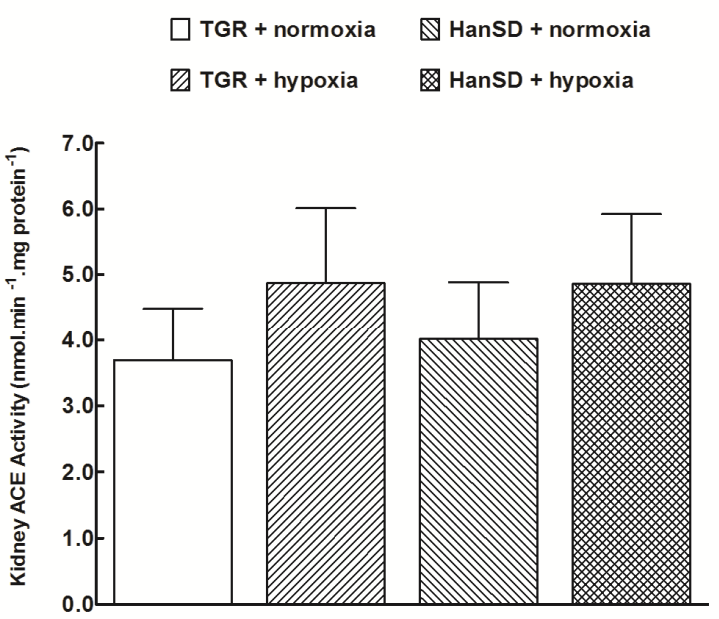

D

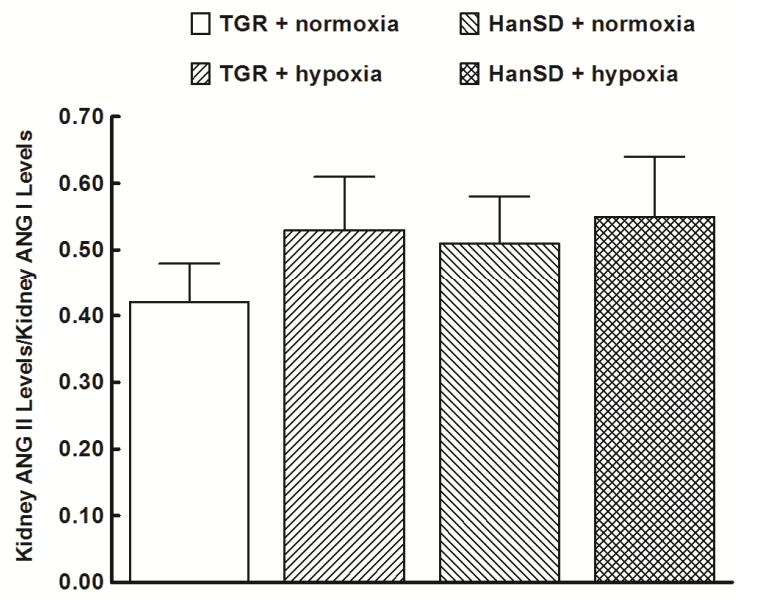

$\mathbf{E}$

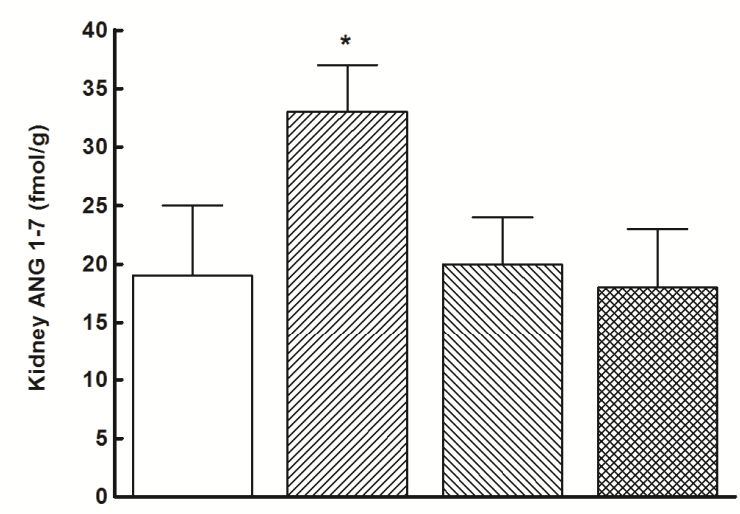

$\mathbf{F}$

$\begin{array}{ll}\square \text { TGR + normoxia } & \mathbb{Q} \text { HanSD + normoxia } \\ \square \text { TGR + hypoxia } & \text { W HanSD + hypoxia }\end{array}$

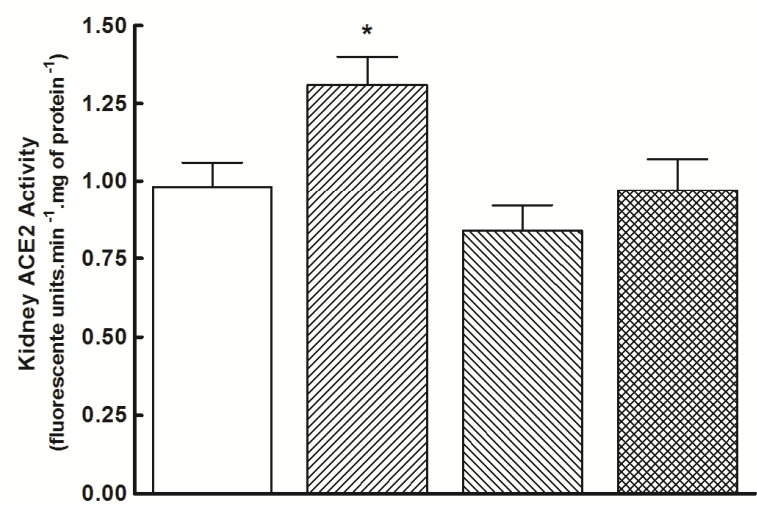

Fig. 3. Kidney angiotensin II (ANG II) levels (A), kidney renin activity (B), kidney angiotensin-converting enzyme (ACE) activity (C) and the ratio of kidney ANG II to angiotensin I (ANG I) levels (D), kidney angiotensin 1-7 (ANG 1-7) levels (E) and kidney angiotensinconverting enzyme type 2 (ACE2) activity (F) in TGR (heterozygous Ren-2 renin transgenic rats) and HanSD (transgene-negative) rats. Values are means \pm SEM. ${ }^{*} P<0.05$ vs. unmarked values; ${ }^{*} P<0.05$ vs. all the other values. 
A
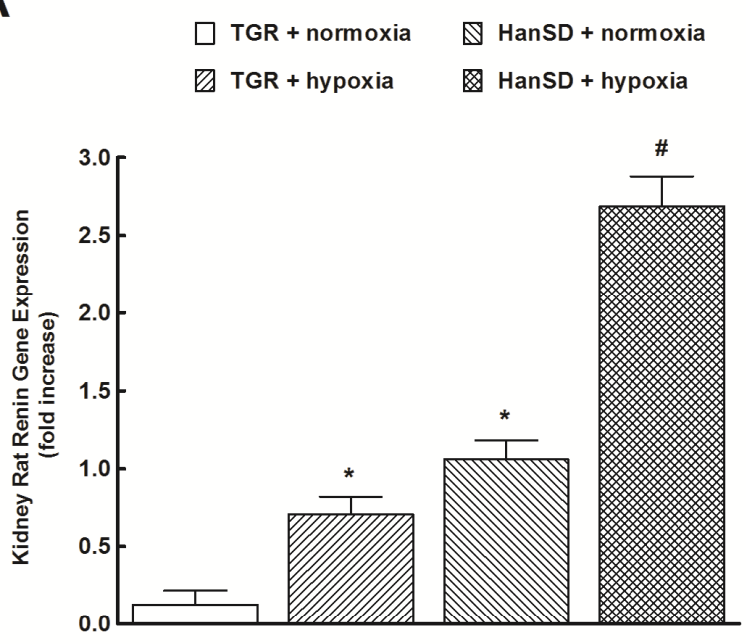

B

$\square$ TGR + normoxia $\quad$ TGR + hypoxia

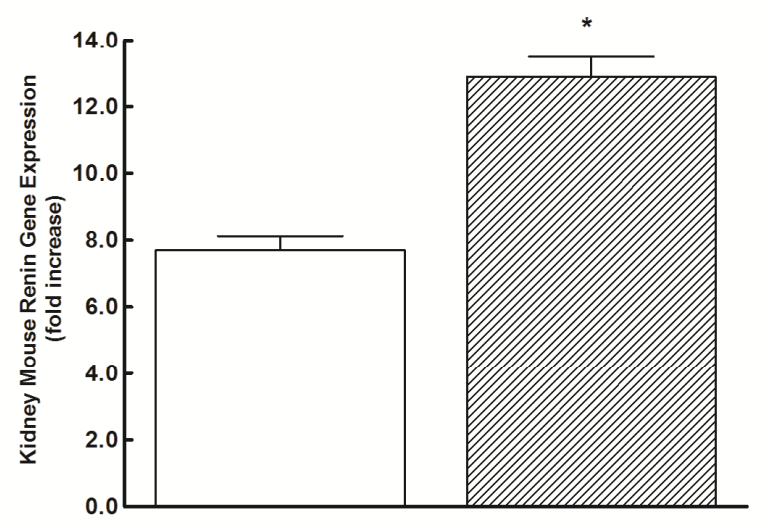

C
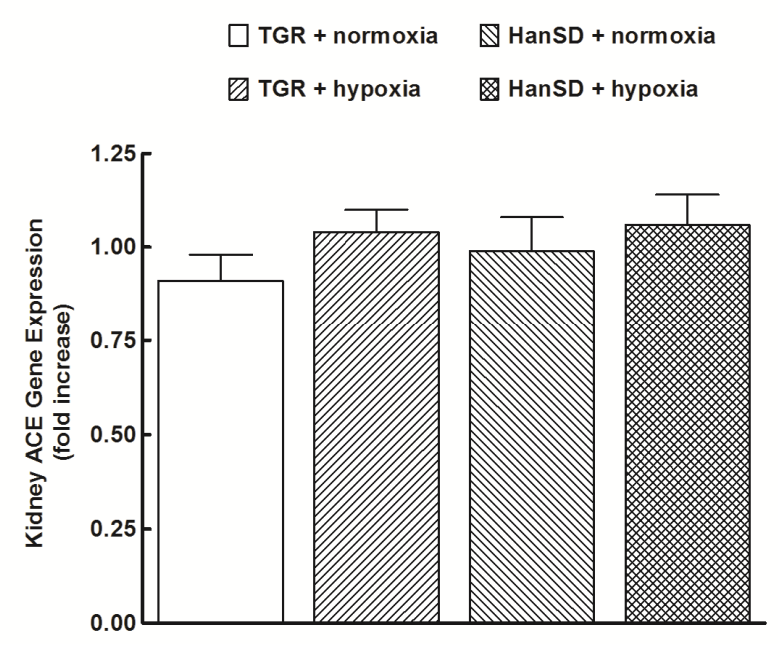

D
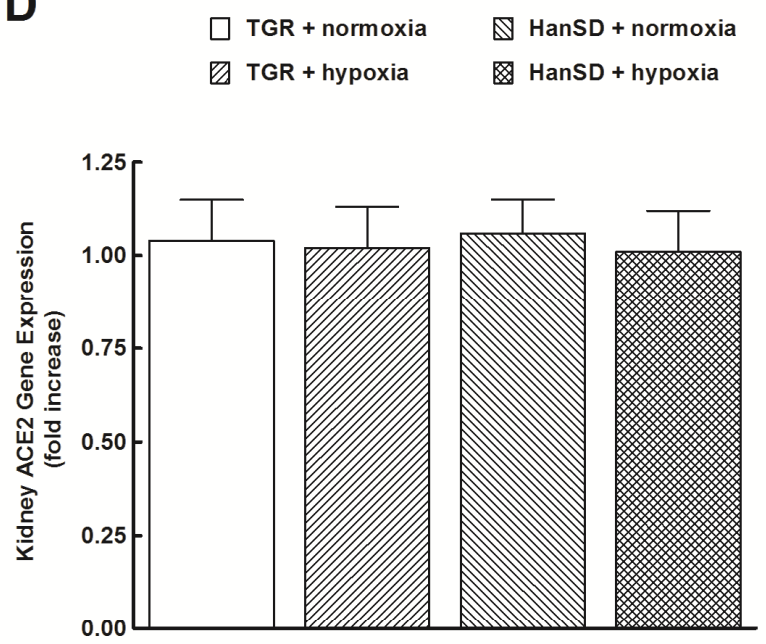

$\mathbf{E}$

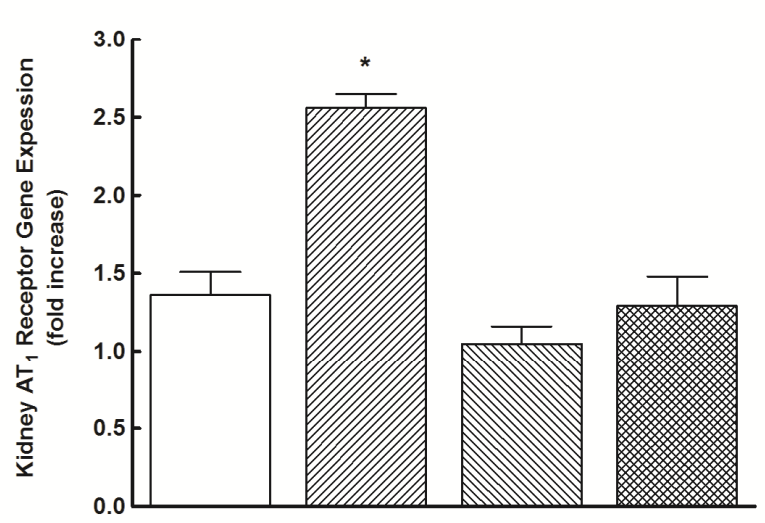

$\mathbf{F}$

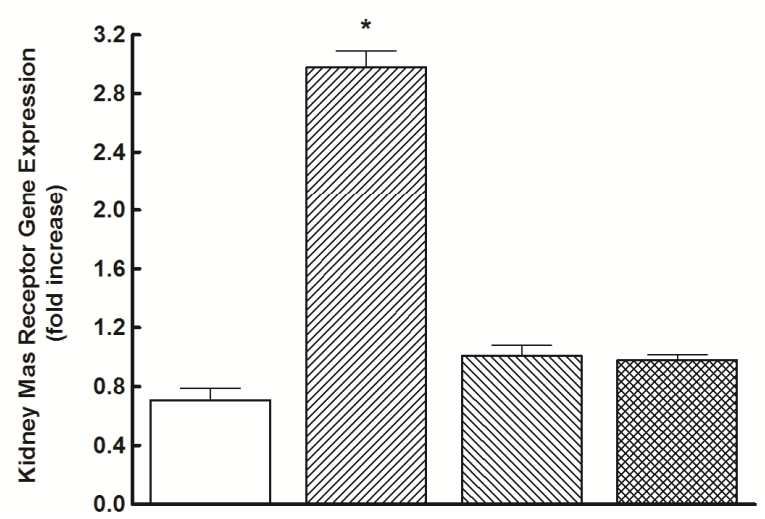

Fig. 4. Kidney rat (A) and mouse renin gene expression (B), kidney angiotensin-converting enzyme (ACE) gene expression (C), kidney angiotensin-converting enzyme type 2 (ACE2) gene expression (D), kidney ANG II type 1 (AT I $_{1}$ ) receptor gene expression (E), and kidney Mas receptor gene expression (F) in TGR (heterozygous Ren-2 renin transgenic rats) and HanSD (transgene-negative) rats. Values are means \pm SEM. $* P<0.05$ vs. unmarked values; ${ }^{\#} \mathrm{P}<0.05$ vs. all the other values. 
As shown in Figure 3A, kidney ANG II concentrations were markedly higher in TGR than in HanSD rats under continuous normoxia (293 \pm 45 vs. $150 \pm 31 \mathrm{fmol} / \mathrm{g}, \mathrm{P}<0.05)$ and exposure to chronic hypoxia caused significant decreases in these levels in TGR and HanSD rats (to $65 \pm 8$ and to $59 \pm 9 \mathrm{fmol} / \mathrm{g}$, respectively; both changes different at $\mathrm{P}<0.05$ from corresponding normoxic controls). As shown in Figure 3B, kidney renin activity was under continuous normoxia significantly lower in TGR as compared with HanSD rats $(27 \pm 4$ vs. $186 \pm 38 \mu \mathrm{g}$ ANG I. $\mathrm{g}$ of tissue $\left.\mathrm{e}^{-1} \cdot \mathrm{h}^{-1}, \mathrm{P}<0.05\right)$ and exposure to hypoxia resulted in profound decreases in these values in TGR as well as in HanSD rats. Kidney ACE activity and the renal ANG II/ANG I ratio did not significantly differ between TGR and HanSD rats under continuous normoxia and chronic exposure to hypoxia did not alter them in TGR or HanSD rats (Figs 3C and 3D). Likewise, kidney ANG 1-7 levels and kidney ACE2 activity did not significantly differ between TGR and HanSD rats under continuous normoxia and exposure to hypoxia significantly increased kidney ANG 1-7 concentrations and kidney ACE2 activity in TGR but did not change them in HanSD rats (Figs 3E and 3F).

Similarly as in the case of catecholamine concentrations in plasma, there were no significant differences under continuous normoxia in kidney epinephrine, norepinephrine and dopamine levels between TGR and HanSD rats $(10.09 \pm 0.81$ vs. $10.74 \pm 0.92,198.8 \pm 7.4$ vs. $206.9 \pm 9.7 \mathrm{ng} / \mathrm{g}$ and $51.2 \pm 3.4$ vs. $45.8 \pm 4.1 \mathrm{pg} / \mathrm{g}$ ) and exposure to hypoxia did not change these values significantly.

As shown in Figure 4A, the expression in kidney tissue of rat renin gene under continuous normoxia was markedly suppressed in TGR as compared with HanSD rats. The exposure to chronic hypoxia significantly increased kidney rat renin gene expression in TGR as well as in HanSD rats, but the magnitude of this increase was markedly higher in the latter. In contrast, as shown in Figure 4B, kidney mouse renin gene was markedly overexpressed and chronic hypoxia further increased this expression. Since the kidney mouse renin gene expression was virtually 0 in HanSD rats, the data are not shown.

Under continuous normoxia there were no significant differences in kidney ACE and ACE2 receptor gene expression in TGR and HanSD rats; the values were not altered by chronic exposure to hypoxia (Figs 3C and 3D). As shown in Figures $3 \mathrm{E}$ and $3 \mathrm{~F}$, there were no significant differences in kidney $\mathrm{AT}_{1}$ and Mas receptor gene expression between TGR and HanSD rats under continuous normoxia, and exposure to chronic hypoxia elicited a significant increase in the expression in TGR but did not alter it in HanSD rats.

Western blot analyses of renal protein expression of $\mathrm{ACE} 2, \mathrm{AT}_{1}$ and Mas receptor confirmed the data obtained by gene expression analyses and therefore are not shown.

\section{Discussion}

The first major finding of the present study was that in TGR a two weeks' exposure to hypoxia resulted in a significant decrease in $\mathrm{BP}$, almost to normotensive levels observed in HanSD rats. After cessation of hypoxia, BP gradually returned to levels observed in TGR under continuous normoxia. We saw that the posthypoxic decrease in BP was associated with marked suppression of plasma and kidney ANG II concentrations, even below the levels observed in age-matched normotensive HanSD rats in continuous normoxia. In addition, we found that 14 days' exposure to chronic hypoxia resulted in significant increases in intrarenal ACE2 activity, ANG 1-7 concentrations and Mas receptor expression. However, the exposure to chronic hypoxia had no significant effect on BP in HanSD rats. Thus, our findings in TGR were actually opposite to the predictions regarding the effects of chronic hypoxia on the hypertension in TGR: instead of aggravation of hypertension chronic hypoxia normalized BP. Therefore, the critical issue in the present study was to explain the mechanism(s) underlying the BP-lowering action of chronic hypoxia in TGR.

In this regard, it is important to note that the critical role of the circulating and especially of the intrarenal RAS in the pathophysiology of hypertension is now well established (Kobori et al. 2007, Červenka et al. 2008, Gonzalez-Vilalobos et al. 2013) and this is particularly true for our TGR model (Husková et al. 2006a,b, 2010, Vaňourková et al. 2006, Červenka et al. 2008, Kujal et al. 2010, 2014, Neckář et al. 2012, Varcabová et al. 2013). A concept has recently emerged that, within the RAS, a newly discovered vasodilatory axis ACE2-ANG 1-7-Mas receptor exists and, under conditions of enhanced RAS activity, counteracts the classical vasoconstrictor ACE-ANG II-AT ${ }_{1}$ receptor axis (Bader et al. 2013, Fraga-Silva et al. 2013, Varagic et al. 2014). Therefore it could be hypothesized that the BP-lowering effect of chronic hypoxia in TGR could be, 
at least in part, mediated via increased activity of this vasodilatory axis. This notion is supported by our present results showing that 14 days' exposure to chronic hypoxia increased intrarenal activity, concentration and expression of individual components of the ACE2-ANG 1-7-Mas receptor axis in TGR and did not alter them in HanSD rats. Our results suggest that increased intrarenal activity of the vasodilatory axis could contribute to the BP-lowering effects of chronic hypoxia in TGR. This concept is further supported by recent findings in twokidney, one-clip (2K1C) Goldblatt hypertensive rats (another model of ANG II-dependent hypertension with increased endogenous intrarenal RAS activity) indicating that both kidneys of $2 \mathrm{~K} 1 \mathrm{C}$ hypertensive rats exhibit reciprocal changes in ACE-ANG II (augmentation) and ACE2-ANG 1-7 (suppression) axis (Prieto et al. 2011) and that impairment of the ACE2-ANG II-Mas receptor axis contributes to the acceleration of hypertension in this model (Bürgelová et al. 2009).

Moreover, since chronic hypoxia did not alter plasma and kidney concentrations of catecholamines, it is unlikely that changes in the sympathetic nervous activity significantly contribute to the BP-lowering effect of chronic hypoxia in TGR. Since we showed that the exposure of TGR to two weeks' hypoxia caused a marked suppression of circulating and intrarenal ANG II, we propose that normalization of inappropriately elevated plasma and kidney ANG II was the main mechanism responsible for the decrease in $\mathrm{BP}$.

What remains, however, is the issue of the mechanism(s) responsible for the suppression of elevated plasma and kidney ANG II levels in TGR exposed to chronic hypoxia. We saw that exposure to chronic hypoxia did not alter plasma or renal ACE activity and intrarenal ACE gene expression in TGR or HanSD rats but significantly reduced plasma and renal renin activity in both rat strains. Our findings that rat renin gene expression in the kidney in continuous normoxia was markedly lower in TGR than in HanSD rats and that mouse renin gene was substantially overexpressed are in accordance with the earlier evidence (Mullins et al. 1990, Bohlender et al. 1998). It indicated that, first, increased ANG II formation in TGR is unequivocally the consequence of overexpression of the mouse renin transgene, and, second, TGR retain the physiological negative feedback effect of increased ANG II levels on endogenous rat renin gene (Castrop et al. 2010). Furthermore, the observation that TGR responded to chronic hypoxia by increased rat as well as mouse renin gene expression suggests that under conditions of renin depletion and reduced ANG II synthesis, TGR retain the feedback control of renin secretion by the baroreceptor of the afferent glomerular arterioles (Castrop et al. 2010). Of special interest are our findings regarding kidney cortex $\mathrm{AT}_{1}$ receptor gene and protein expression because we found that $\mathrm{AT}_{1}$ receptor expression in TGR in continuous normoxia is maintained at the same level as in HanSD rats, despite increased BP and intrarenal ANG II concentrations. The sustained kidney $\mathrm{AT}_{1}$ receptor expression can be considered as inappropriately high for the level of BP and ANG II concentrations observed in TGR. However, our observations are in agreement with the finding of Harrison-Bernard et al. (1999, 2002) who found that ANG II-infused rats also do not exhibit downregulation of kidney $\mathrm{AT}_{1}$ receptor expression despite marked hypertension and elevation of ANG II levels. Even though it was originally claimed that $\mathrm{AT}_{1}$ receptors in the kidney are under negative feedback regulation by ANG II (elevated ANG II concentrations downregulate and decreased ANG II concentrations upregulate them) (Douglas 1987), uncertainty remains regarding the effects of chronically increased ANG II concentrations on $\mathrm{AT}_{1}$ receptors expression in the kidney. Notably, a number of studies failed to detect changes in $\mathrm{AT}_{1}$ receptors expression in the kidney in response to chronic alterations in ANG II concentrations induced either pharmacologically or by long-term modification of dietary salt intake (Schmidt et al. 1997, Wang et al. 1998, Harrison-Bernard et al. 1999, 2002, Husková et al. 2006a). This contradiction is also apparent in our present study: on one hand the exposure to 14 days' hypoxia caused upregulation of $\mathrm{AT}_{1}$ receptors in the kidney in TGR and, on the other hand, the same procedure did not significantly change $\mathrm{AT}_{1}$ receptor expression in HanSD rats.

Collectively, with the above-discussed observations in mind, we suggest that the inhibition of plasma and kidney renin activity is the main cause of the suppression of increased plasma and kidney ANG II in TGR exposed to chronic hypoxia. The precise mechanism(s) responsible for this suppression and the question if such mechanism(s) are specific to TGR only or are operative in all ANG II-dependent models of hypertension require a separate study. However, in this context it is important to note that already 25 years ago similar BP-responses to exposure chronic hypoxia were observed in spontaneously hypertensive rats (SHR) a genetic model of human primary hypertension (Zicha 
and Kunes 1999), i.e. decreases in BP and attenuation of cardiac hypertrophy during exposure to chronic hypoxia and after returning to normoxia increases in BP to levels observed in SHR maintained on continuous normoxia (Henley and Tucker 1986, Henley et al. 1992). Even if SHR is not an ANG II-dependent model of hypertension (Zicha and Kunes 1999) and activities/concentrations of individual components of RAS were not evaluated at those studies, these findings are of special interest, because it might indicate that BP and RAS responses to chronic hypoxia might exhibit similar pattern in many rat hypertensive models.

Another important question regards the mechanism(s) responsible for augmentation of the activity of the intrarenal ACE2-ANG-Mas receptor axis in TGR exposed to chronic hypoxia. Since recent studies have demonstrated that ANG II downregulates ACE2 expression and activity and Mas receptor expression in various tissue, especially in kidney cortex (Ferrario et al. 2005, Gallagher et al. 2006, Koka et al. 2008, Varagic et al. 2014), and because ACE2 is thought to be the major enzyme involved in ANG 1-7 formation (Bader 2013, Fraga-Silva et al. 2013, Varagic et al. 2014), we propose that increased intrarenal ACE2 activity, ANG 1-7 concentration and Mas receptor expression is the consequence of decreased intrarenal ANG II levels and interruption of the negative feedback loop in TGR exposed to chronic hypoxia.

Collectively, our present study suggest that suppression of the hypertensiogenic ACE-ANG II-AT receptor axis in the circulation and kidney tissue combined with activation of the intrarenal vasodilator ACE2-ANG 1-7-Mas receptor axis is the main mechanism explaining BP-lowering effects of chronic hypoxia in TGR. Obviously, further studies are needed to clarify if these hypotensive effects of chronic hypoxia are specific for TGR only or are a feature characteristic for all ANG II-dependent models of hypertension.

\section{Conflict of Interest}

There is no conflict of interest.

\section{Acknowledgements}

This study was supported by the grant No. NT/14085-5 awarded by the Internal Grant Agency of the Ministry of Health of the Czech Republic to Z.H. L.C. is also supported by the project of the Ministry of Health of the Czech Republic for the development of research organization 00023001 (IKEM) (institutional support). S.J. is supported the Grant Agency of Charles University No. 266213. The Center for Experimental Medicine (IKEM) received financial support from the European Commission within the Operational Program Prague - Competitiveness; project "CEVKOON" (\#CZ.2.16/3.1.00/22126) and this study was also result of noncommercial cooperation between IKEM and OMNIMEDICS Ltd. within the project "CEVKOON". J.H and V.H are supported by the grant No. 13-01710S from the Grant Agency of the Czech Republic.

\section{References}

ANTEZANA AM, RICHALET JP, NORIEGA I, GALARZA M, ANEZANA G: Hormonal changes in normal and polycythemic high-altitude natives. $J$ Appl Physiol 79: 795-800, 1995.

BADER M: ACE2, angiotensin-(1-7), and Mas: the other side of the coin. Pflugers Arch 465: 79-85, 2013.

BOHLENDER J, MENARD J, EDLING O, GANTEN D, LUFT FC: Mouse and rat plasma renin concentration and gene expression in (mRen2)27 transgenic rats. Am J Physiol 274: H1450-H1456, 1998.

BURGELOVÁ M, VAŇOURKOVÁ Z, THUMOVÁ M, DVOŘÁK P, OPOČENSKÝ M, KRAMER HJ, ŽELÍZKO M, MALÝ J, BADER M, ČERVENKA L: Impairment of the angiotensin-converting enzyme 2-angiotensin-(1-7)Mas axis contributes to the acceleration of two-kidney, one-clip Goldblatt hypertension. J Hypertens 27: 1988-2000, 2009.

CASTROP H, HOCHERL K, KURTZ A, SCHWEDA F, TOTOROV V, WAGNER C: Physiology of kidney renin. Physiol Rev 90: 607-673, 2010.

CERVENKA L, HELLER J: Comparison of the effects of a low-protein diet with the effects of a converting enzyme inhibitor on the progression of renal insufficiency in hypertensive rats. Ren Fail 18: 173-180, 1996. 
ČERVENKA L, VANĚČKOVÁ I, HUSKOVÁ Z, VAŇOURKOVÁ Z, ERBANOVÁ M, THUMOVÁ M, ŠKAROUPKOVÁ P, OPOČENSKÝ M, MALÝ J, ČERTÍKOVÁ CHÁBOVÁ V, TESAŘ V, BURGELOVÁ M, VIKLICKÝ O, TEPLAN V, ŽELÍZKO M, KRAMER HJ, NAVAR LG: Pivotal role of $\mathrm{AT}_{1 \mathrm{~A}}$ receptors in the development of two-kidney, one-clip hypertension: study in $\mathrm{AT}_{1 \mathrm{~A}}$ receptor knockout mice. J Hypertens $\mathbf{2 6}$ : 1379-1389, 2008.

DOUGLAS JG: Angiotensin receptor subtypes of the kidney cortex. Am J Physiol 253: F1-F7, 1987.

FERRARIO CM, JESSUP J, GALLAGHER PE, AVERILL DB, BROSNIHAN KB, TALLANT EA, SMITH RD, CHAPPELL MC: Effects of renin-angiotensin system blockade on renal angiotensin-(1-7) forming enzymes and receptors. Kidney Int 68: 2189-2196, 2005.

FRAGA-SILVA RA, FERREIRA AJ, DOS SANTOS RAS: Opportunities for targeting the angiotensin-converting enzyme 2/Angiotensin-(1-7)Mas receptor pathway in hypertension. Curr Hypertens Rep 15: 31-38, 2013.

FRASER R, RENNIE ID, GRAY GW, HOUSTON CS: Hormonal and electrolyte response to exposure to 17,500 ft. J Appl Physiol 38: 636-642, 1975.

GALLAGHER PE, CHAPPEL MC, FERRARIO CM, TALLANT EA: Distinct roles for ANG II and ANG-(1-7) in the regulation of angiotensin-converting 2 in rat astrocytes. Am J Physiol 290: C420-C426, 2006.

GIANI JF, MIQUET JG, MUNOZ MC, BURGHI V, TOBLI JE, MASTERNAK MM, KOPCHICK JJ, BARTKE A, TURYN D, DOMINICI FP: Upregulation of the angiotensin-converting enzyme 2/angiotensin-(1-7)/Mas receptor axis in the heart and the kidney of growth hormone receptor knock-out mice. Growth Horm IGF Res 22: 224-233, 2012.

GONZALES-VILALOBOS RA, JANJOUILIA T, FLETECHER NK, GIANI JF, NGUYEN MT, RIQUIER-BRISON AD, SETH DM, FUCHS S, ELADARI D, PICARD N, BACHMANN S, DELPIRE E, PETI-PETERDI J, NAVAR LG, BERNSTEIN KE, MCDOUNOUGH AA: The absence of intrarenal ACE protects against hypertension. J Clin Invest 123: 2011-2023, 2013.

GUILD SJ, MCBRYDE FD, MALPAS SC, BARRETT CJ: High dietary salt and angiotensin II chronically increase renal sympathetic nerve activity: a direct telemetric study. Hypertension 59: 614-620, 2012.

HAMPL V, BÍBOVÁ J, OŠŤÁDALOVÁ I, POVÝŠILOVÁ V, HERGET J: Gender differences in the long-term effects of perinatal hypoxia on pulmonary circulation in rats. Am J Physiol 285: L386-L392, 2003.

HARRISON-BERNARD LM, EL-DAHR SD, O'LEARY DF, NAVAR LG: Regulation of angiotensin II type 1 receptor mRNA and protein in angiotensin II-induced rats. Hypertension 33: 340-346, 1999.

HARRISON-BERNARD LM, ZHOU J, KOBORI H, OHISHI M, NAVAR LG: Intrarenal $\mathrm{AT}_{1}$ receptor and ACE binding in ANG II-induced hypertensive rats. Am J Physiol 281: F19-F25, 2002.

HENLEY WN, TUCKER A: Attenuation of $\alpha$-adrenergic responsiveness in hypoxic SHR. Clin Exp Hypertens 8: 1355$1371,1986$.

HENLEY WN, BELLUSH LL, NOTESTINE MA: Reemergence of spontaneous hypertension in hypoxia-protected rats returned to normoxia as adults. Brain Res 579: 211-218, 1992.

HERGET J, PELOUCH V, KOLÁŘ F, OŠŤÁDAL B: The inhibition of angiotensin converting enzyme attenuates the effects of chronic hypoxia on pulmonary blood vessels in the rat. Physiol Res 45: 221-226, 1996.

HERRERA M, SPARKS MA, ALFONSO-PECCHIO AR, HARRISON-BERNARD LM, COFFMAN TM: Lack of specificity of commercial antibodies leads to misidentification of angiotensin type 1 receptor protein. Hypertension 61: 253-258, 2013.

HOEHNE C, KREBS MO, BOEMKE W, ARNTZ E, KACZMARCZYK G: Evidence that renin decrease during hypoxia is adenosine mediated in conscious dogs. $J$ Appl Physiol 90: 1842-1848, 2001.

HOUBLOUE I, RONDELET B, KERBAUL F, BIARENT D, MILANI GM, STAROUKINE M, BERGMANN P, NAEIJE R, LEEMAN M: Endogenous angiotensin II in the regulation of hypoxic pulmonary vasoconstriction in anaesthetized dogs. Critical Care 8: R163-R173, 2004.

HUSKOVÁ Z, KRAMER HJ, VAŇOURKOVÁ Z, ČERVENKA L: Effects of changes in sodium balance on plasma and kidney angiotensin II levels in anesthetized and conscious Ren-2 transgenic rats. J Hypertens 24: 517-527, 2006a. 
HUSKOVÁ Z, KRAMER HJ, THUMOVÁ M, VAŇOURKOVÁ Z, BURGELOVÁ M, TEPLAN V, MALÝ J, ČERVENKA L: Effects of anesthesia on plasma and kidney ANG II levels in normotensive and ANG IIdependent hypertensive rats. Kidney Blood Press Res 29: 74-83, $2006 \mathrm{~b}$.

HUSKOVÁ Z, VAŇOURKOVÁ Z, ERBANOVÁ M, THUMOVÁ M, OPOČENSKÝ M, MULLINS JJ, KRAMER HJ, BURGELOVÁ M, ČERVENKA L: Inappropriately high circulating and intrarenal angiotensin II levels during dietary salt loading exacerbate hypertension in Cyp1a1-Ren-2 transgenic rats. J Hypertens 28: 495-509, 2010.

JANCOVSKI N, BASSI JK, CARTER DA, CHOONG YT, CONNELLY A, NGUYEN TP, CHEN D, LUKOSHKOVA EV, MENUET C, HEAD GA, ALLEN AM: Stimulation of angiotensin type 1A receptors on catecholaminergic cells contributes to angiotensin-dependent hypertension. Hypertension 62: 866-871, 2013.

KOBORI H, NANGAKU M, NAVAR LG, NISHIYAMA A: The intrarenal renin-angiotensin system: from physiology to the pathobiology of hypertension and kidney disease. Pharmacol Rev 59: 251-287, 2007.

KOKA V, HUANG XR, CHUNG ACK, WANG W, TRUONG LD, LAN HY: Angiotensin II upregulates angiotensin I-converting enzyme (ACE), but dowregulates ACE2 via the AT1-ERK/p38 MAP kinase pathway. Am $J$ Pathol 172: 1174-1183, 2008.

KREBS MO, BOEMKE W, SIMON S, WENZ M, KACZMARCZYK G: Acute hypoxic pulmonary vasoconstriction in conscious dogs decreases renin and is unaffected by losartan. J Appl Physiol 86: 1914-1919, 1999.

KUJAL P, ČERTÍKOVÁ CHÁBOVA V, VERNEROVÁ Z, WALKOWSKA A, KOMPANOVSKA-JEZIERSKA E, SADOWSKI J, VAŇOURKOVÁ $Z$, HUSKOVÁ $Z$, OPOČENSKÝ M, ŠKAROUPKOVÁ P, SCHEJBALOVÁ S, KRAMER HJ, RAKUŠAN D, MALÝ J, NETUKA I, VANĚČKOVÁ I, KOPKAN L, CERVENKA L: Similar renoprotection after renin-angiotensin-dependent and -independent antihypertensive therapy in 5/6-nephrectomized Ren-2 transgenic rats: are there blood pressure-independent effects? Clin Exp Pharmacol Physiol 37: 1159-1169, 2010.

KUJAL P, ČERTÍKOVÁ CHÁBOVÁ V, ŠKAROUPKOVÁ P, HUSKOVÁ Z, VERNEROVÁ Z, KRAMER HJ, WALKOWSKA A, KOMPANOVSKA-JEZIERSKA E, SADOWSKI J, KITADA K, NISHIYAMA A, HWANG SH, HAMMOCK BD, IMIG JD, ČERVENKA L: Inhibition of soluble epoxide hydrolase is renoprotective in 5/6 nephrectomized Ren-2 transgenic hypertensive rats. Clin Exp Pharmacol Physiol 41: 227-237, 2014.

KURTZ TW, GRIFFIN KA, BIDANI AK, DAVISSON RL, HALL JE: Recommendations for blood pressure measurements in humans and experimental animals. Part 2: Blood pressure measurements in experimental animals. Hypertension 45: 299-310, 2005.

MORRELL NW, MORRIS KG, STENMAR KR: Role of angiotensin-converting enzyme and angiotensin II in the development of hypoxic pulmonary hypertension. Am J Physiol 38: H1186-H1194, 1995.

MULLINS JJ, PETERS J, GANTEN D: Fulminant hypertension in transgenic rats harboring the mouse Ren-2 gene. Nature 344: 541-544, 1990.

NECKÁŘ J, KOPKAN L, HUSKOVÁ Z, KOLÁŘ F, PAPOUŠEK F, KRAMER HJ, HWANG SH, HAMMOCK BD, IMIG JD, MALÝ J, NETUKA I, OŠŤÁDAL B, ČERVENKA L: Inhibition of soluble epoxide hydrolase by cis-4-[4-(3-adamantan-I-ylureido)cyclohexyl-oxy]benzoic acid exhibits antihypertensive and cardioprotective actions in transgenic rats with angiotensin II-dependent hypertension. Clin Sci 122: 513-525, 2012.

NOGUEIRA EF, VARGAS CA, OTIS M, GALLO-PAYET N, BOLLAG WB, RAINEY WE: Angiotensin-II acute regulation of rapid response genes in human, bovine, and rat adrenocortical cells. $J$ Mol Endocrinol 39: 365-374, 2007.

PRIETO MC, GONZÁLEZ-VILLALOBOS RA, BOTROS FT, MARTIN VL, PAGÁN J, SATOU R, LARA LS, FENG Y, FERNANDES FB, KOBORI H, CASARINI DE, NAVAR LG: Reciprocal changes in renal ACE/ANG II and ACE2/ANG 1-7 are associated with enhanced collecting duct renin in Goldblatt hypertensive rats. Am J Physiol 300: F749-F755, 2011.

ROSE CE JR, KIMMEL DP, GODINE RL, KAISER DL, CAREY RM: Synergistic effects of acute hypoxemia and hypercapnic acidosis in conscious dogs. Renal dysfunction and activation of the renin-angiotensin system. Circ Res 53: 202-213, 1983. 
SCHMID C, CATROP H, REITBAUER J, BRUNA RD, KURTZ A: Dietary salt intake modulates angiotensin II type 1 receptor gene expression. Hypertension 29: 923-929, 1997.

VAŇOURKOVÁ Z, KRAMER HJ, HUSKOVÁ Z, VANĚČKOVÁ I, OPOČENSKÝ M, ČERTÍKOVÁ CHÁBOVÁ V, TESǍ̌ V, ŠKAROUPKOVÁ P, THUMOVÁ M, DOHNALOVÁ M, MULLINS JJ, ČERVENKA L: $\mathrm{AT}_{1}$ receptor blockade is superior to conventional triple therapy in protecting against end-organ damage Cypla1-Ren-2 transgenic rats with inducible hypertension. J Hypertens 24: 2465-2472, 2006.

VARAGIC J, AHMAD S, NAGATA S, FERRARIO CM: ACE2: angiotensin II/angiotensin-(1-7) balance in cardiac and renal injury. Curr Hypertens Rep 16: 420-429, 2014.

VARCABOVÁ Š, HUSKOVÁ Z, KRAMER HJ, HWANG SH, HAMMOCK BD, IMIG JD, KITADA K, ČERVENKA L: Antihypertensive action of soluble epoxide hydrolase inhibition in Ren-2 transgenic rats is mediated by suppression of the intrarenal renin-angiotensin system. Clin Exp Pharmacol Physiol 40: 273-281, 2013.

VILAR J, WAECKE L, BONNIN P, COCHAIN C, LOINARD C, DURIEZ M, SILVESTRE JS, LÉVY BI: Chronic hypoxia-induced angiogenesis normalizes blood pressure in spontaneously hypertensive rats. Circ Res 103: 761-769, 2008.

WANG DH, DU Y: Regulation of vascular type 1 angiotensin II receptor in hypertension and sodium loading: role of angiotensin II. J Hypertens 16: 467-475, 1998.

WONG TP, HO KY, NG EKW, DEBNAM ES, LEUNG PS: Upregulation of ACE-ANG-(1-7)-Mas axis in jejunal enterocytes of type 1 diabetic rats: implication for glucose transport. Am J Physiol 303: E669-E681, 2012.

ZAKHEIM RM, MOLTENI A, MATTIOLI L, PARK M: Plasma angiotensin II levels in hypoxic and hypovolemic stress in unanesthetized rabbits. J Appl Physiol 41: 462-465, 1976.

ZICHA J, KUNES J: Ontogenetic aspects of hypertension development: analyses in the rat. Physiol Rev 79: 1227-1282, 1999.

ZOU LX, IMIG JD, HYMEL A, NAVAR LG: Renal uptake of circulating angiotensin II in Val ${ }^{5}$-angiotensin II infused rats is mediated by $\mathrm{AT}_{1}$ receptor. Am J Hypertens 11: 570-578, 1998. 